\title{
Partial Nephrectomy for Stage I Renal Cell Carcinoma: On-clamp or Off-clamp?
}

\section{Evre I Böbrek Tümöründe Parsiyel Nefrektomi: Iskemili mi? İskemisiz mi?}

\author{
Kaan Çömez, Serdar Çelik, Ozan Bozkurt, Ömer Demir, Güven Aslan, Adil Esen \\ Dokuz Eylül University Faculty of Medicine, Department of Urology, İmir, Turkey
}

\section{What's known on the subject? and What does the study add?}

Partial nephrectomy is the standard surgical approach for small renal tumors. Different techniques may have different outcomes in terms of cancer control, renal functions and complications. The present study explores the possible differences between the evaluated operation techniques.

\begin{abstract}
Objective

Partial nephrectomy represents the gold standard surgical procedure for the treatment of small renal cortical tumors. Tumor resection may be performed with the following techniques: on-clamp (warm or cold ischemia) and offclamp (zero-ischemia). We aimed to share our experience with these two techniques and compare treatment outcomes in the present study.

\section{Materials and Methods}

Patients who have undergone open partial nephrectomy for clinical stage I renal cell carcinoma in our department between 2008 and 2012 were enrolled. Group 1 comprised patients with off-clamp technique and group 2 with on-clamp technique. Demographic data, length of operation, length of hospitalization, preoperative estimated glomerular filtration rate (eGFR) and postoperative eGFR on the last visit, complications and requirement of additional procedures, pathologic stage, and surgical margin status were compared between the groups retrospectively.

\section{Results}

A total of 73 patients, 40 in group 1 and 33 in group 2, were included in the study. Mean age, rate of comorbidities, R.E.N.A.L. nephrometry scores, preoperative eGFR, length of operation, length of hospitalization, complications, surgical margin status and additional procedure requirement did not differ significantly between the groups. Transfusion requirement was higher in group 1, however, it did not reach statistical significance $(0.7 \pm 1.2$ $U$ vs. $0.2 \pm 0.5 U, p=0.066)$. After a median follow-up of 27 months for group 1 and 33 months for group 2, postoperative eGFR values were also similar $\left(72.6 \pm 31.0 \mathrm{ml} / \mathrm{min} / 1.73 \mathrm{~m}^{2}\right.$ vs. $\left.78.3 \pm 22.3 \mathrm{ml} / \mathrm{min} / 1.73 \mathrm{~m}^{2}, p=0.651\right)$.
\end{abstract}

\section{Conclusion}

Both surgical techniques, on-clamp and off-clamp partial nephrectomy, can be performed according to the surgeons' preferences safely with similar outcomes.

\section{Keywords}

Ischemia, partial nephrectomy, renal cell carcinoma

\section{ÖZ}

Amaç

Parsiyel nefrektomi küçük renal kortikal tümörler için altın standart tedavidir. Parsiyel nefrektomi iskemili ve iskemisiz olarak yapılabilmektedir. Biz bu çalışmada kliniğimizde yapılan iskemili ve iskemisiz açık parsiyel nefrektomi deneyimlerimizi paylaşmayı amaçladık.

\section{Gereç ve Yöntem}

Kliniğimizde 2008 ve 2012 yılları arasında klinik evre 1 renal hücreli karsinom için açık parsiyel nefrektomi yapılan hastalar değerlendirildi. Grup 1 hastalar iskemi uygulanmayan ve grup 2 hastalar iskemi uygulanan olmak üzere iki gruba ayrıldı. İki grubun demografik verileri, operasyon süresi, hospitalizasyon süresi, preoperatif glomerüler filtrasyon hızı (GFH) değeri ile son vizit tarihindeki GFH değeri, postoperatif dönemde ek girişim gereksinimi, postoperatif patolojik evre ve cerrahi sınır açısından retrospektif olarak değerlendirildi ve karşılaştırıldı.

\section{Bulgular}

Grup 1'de 40 hasta, grup 2'de 33 hasta olmak üzere toplamda 73 hasta çalışmaya alındı. Her iki grubun ortalama yaş, komorbidite, R.E.N.A.L nefrometri skoru, preoperatif eGFH, operasyon süresi, hospitalizasyon süresi, postoperatif dönemde ek girişim gereksinimi, komplikasyon ve cerrahi sınır açısından benzerdi. Grup 1'de transfüzyon ihtiyacı daha yüksekti ama sonuç istatiksel olarak anlamlı değildi $(0,7 \pm 1,2 \mathrm{U}$ vs. $0,2 \pm 0,5 \cup, p=0,066)$. Ortalama takip süresi grup 1 için 27 ay, grup 2 için 33 ay idi. Postoperatif eGFH sonuçları benzerdi $\left(72,6 \pm 31,0 \mathrm{ml} / \mathrm{min} / 1,73 \mathrm{~m}^{2}\right.$ vs. $\left.78,3 \pm 22.3 \mathrm{ml} / \mathrm{min} / 1,73 \mathrm{~m}^{2}, \mathrm{p}=0,651\right)$.

\section{Sonuç}

İskemili ve iskemisiz parsiyel nefrektomi yöntemlerinin ikisi de cerrahların deneyimine göre etkin ve güvenli bir şekilde uygulanabilir.

\section{Anahtar Kelimeler}

Böbrek tümörleri, iskemi, parsiyel nefrektomi

\section{Correspondence}

Ozan Bozkurt MD, Dokuz Eylül University Faculty of Medicine, Department of Urology, İzmir, Turkey

Phone: +90 2324123451 E-mail: drozanbozkurt@gmail.com Received: 27.04.2016 Accepted: 29.04.2016

This manuscript was presented in $2^{\text {nd }}$ National Urological Surgery Congress. 


\section{Introduction}

Renal cell carcinoma represents 2-3\% of all cancers, with higher incidences in developed regions (1). As a result of rapid technological developments and easy access to imaging modalities, there has been a visible increase in incidentally detected renal masses and this has led to more widespread use of partial nephrectomy. The main objective of partial nephrectomy is to preserve as much functional renal parenchyma as possible with following the oncological principles. Partial nephrectomy is usually performed with warm/cold ischemia for the control of bleeding after tumor resection. Ischemia/reperfusion injury may further damage the kidney resulting in deterioration in renal functions. Ischemia/reperfusion injury does not generally cause any clinical problem in patients with normal preoperative kidney function, whereas it may result in worsening of kidney function in patients with solitary kidney or chronic kidney disease. Renal functions usually decline if warm ischemia time exceeds twenty minutes which is generally regarded as a cut-off time limit (2). Surgical techniques, such as early unclamping (3), selective renal parenchymal clamping (4) and partial clamping (5) have been introduced in order to reduce warm ischemia time and minimize ischemia/reperfusion injury. Zero ischemia technique has also been described under controlled hypotension and microvascular dissection of tumor-specific vessels abandoning global ischemia of the kidney $(6,7)$. Long-term kidney functions in patients who have undergone partial nephrectomy in our department with or without ischemia are explored in the present study.

\section{Materials and Methods}

Charts of the patients, who have undergone open partial nephrectomy for clinical stage I renal cell carcinoma in our department, were retrospectively reviewed. They were divided into two groups according to the ischemia status. Group 1 comprised patients who were operated with off-clamp technique without global ischemia and group 2 with on-clamp technique with warm ischemia. Warm ischemia is preferred to cold ischemia because of better visualisation of the surgical field. Onclamp or off-clamp technique was performed according to surgeon's preference. All procedures were performed under general anesthesia using the flank approach and enucleoresection technique. Renal hilar dissection and renal artery identification was performed in both groups. Mannitol infusion was started 10 minutes before clamping for on-clamp technique and the renal artery was clamped with a bulldog vascular clamp. No occlusion or compression was performed in patients in the off-clamp group. Renoraphy after tumor removal was performed with both internal stitches and also using PTFE Teflon felt in both groups. Age, comorbidity status [diabetes mellitus (DM), hypertension (HT)], transfusion requirement, ischemia time, R.E.N.A.L nephrometry scores, preoperative and postoperative estimated glomerular filtration rates (eGFRs) calculated by the Modification of Diet in Renal Disease formula, length of hospitalization, complication rates, postoperative auxillary procedures, postoperative pathological stage, and surgical margin status were retrospectively analyzed and compared between the groups. R.E.N.A.L nephrometry scores were calculated according to the original report described by Kutikov and Uzzo (8) in 2009.

\section{Statistical Analysis}

Descriptive data were analyzed and t-test was used for the comparison of numerical variables between the groups with SPSS software version 20. A p value of less than 0.05 was deemed statistically significant.

\section{Results}

A total of 73 patients were included with 40 patients in group 1 and 33 patients in group 2. The median follow-up time was 27 months for group 1 and 33 months for group 2. Seventeen patients had DM (11 in group 1 and 6 in group 2) and 35 patients had HT (22 in group 1 and 13 in group 2) at admission. Mean age, length of operation and hospitalization, maximum tumor diameter and R.E.N.A.L nephrometry score were similar between the groups (Table 1). Average ischemia duration was $18.3 \pm 7.9(5-40)$ minutes in group 2. Transfusion requirement was less in group 2 compared to group 1 though the difference was not statistically significant. Preoperative and postoperative eGFR did not differ significantly between the groups (Table 1). Surgical margins were positive for tumor in 20\% and 15.2\% of patients in group 1 and 2, respectively. Twenty-five, 9, 3, 2 and 1 patient had pathological stage $\mathrm{T} 1 \mathrm{a}, \mathrm{T} 1 \mathrm{~b}, \mathrm{~T} 2 \mathrm{a}$, T3a and $\mathrm{T} 4$ disease, respectively in group 1. Twenty-five and 8 patients had pathological stage T1a and T1b disease, respectively in group 2 . Three patients in group 1 underwent double-J catheter insertion due to prolonged urinary drainage and one of the three patients, whose drainage did not resolve, underwent percutaneous fibrin glue application. One patient in group 2 needed double-J catheter insertion and two patients had wound dehiscence in group 2.

\section{Discussion}

Partial nephrectomy for kidney tumors was first described by Czerny (9) in 1887. It has been the gold standard surgical approach for small

Table 1. Comparison of outcomes between group 1 (off-clamp technique) and group 2 (on-clamp technique)

\begin{tabular}{|l|l|l|l|}
\hline & $\begin{array}{l}\text { Group 1 off-clamp } \\
(\mathrm{n}=40)\end{array}$ & $\begin{array}{l}\text { Group 2 on-clamp } \\
(\mathrm{n}=33)\end{array}$ & $p$ \\
\hline Age (years) & $57.9 \pm 12.8$ & $56.2 \pm 11.9$ & 0.560 \\
\hline $\begin{array}{l}\text { Tumor diameter } \\
\text { (mm) }\end{array}$ & $37.6 \pm 15.4$ & $34.8 \pm 11.2$ & 0.645 \\
\hline $\begin{array}{l}\text { R.E.N.A.L } \\
\text { nephrometry } \\
\text { score }\end{array}$ & $6.6 \pm 0.3$ & $6.6 \pm 0.4$ & 0.962 \\
\hline $\begin{array}{l}\text { Transfusion } \\
\text { requirement (U) }\end{array}$ & $0.7 \pm 1.2$ & $0.2 \pm 0.5$ & 0.066 \\
\hline $\begin{array}{l}\text { Operation time } \\
\text { (minutes) }\end{array}$ & $157.5 \pm 45.7$ & $150.9 \pm 40.7$ & 0.522 \\
\hline $\begin{array}{l}\text { Hospitalization } \\
\text { time (days) }\end{array}$ & $7 \pm 5$ & $6.8 \pm 4$ & 0.859 \\
\hline $\begin{array}{l}\text { Preoperative eGFR } \\
\text { (ml/dk/1.73 m²) }\end{array}$ & $75.4 \pm 29.6$ & $87.2 \pm 22.2$ & 0.375 \\
\hline $\begin{array}{l}\text { Postoperative } \\
\text { eGFR } \\
\text { (ml/dk/1.73 m2) }\end{array}$ & $72.6 \pm 31.0$ & $78.3 \pm 22.3$ & 0.651 \\
\hline eGFR: Estimated glomerular filtration rate & & \\
\hline
\end{tabular}


kidney tumors by preserving kidney functions and demonstrating equivocal oncological outcomes with radical nephrectomy during the last decade $(10,11)$. R.E.N.A.L nephrometry score was developed by Kutikov and Uzzo (8) in 2009 for the evaluation of renal masses in terms of complexity, surgical approach and estimation of complications as well as standardization of data regarding operation outcomes. Rosevear et al. (12) have reported that patients who underwent radical nephrectomy had higher mean R.E.N.A.L nephrometry score than patients undergoing partial nephrectomy, highlighting that radical nephrectomy may be preferred in daily practice for more complex tumors and this scoring system may aid in surgical approach. We also used R.E.N.A.L nephrometry score for measuring tumor complexity and standardizing the comparison of the two surgical approaches. Average R.E.N.A.L nephrometry scores in the two groups were nearly identical providing a more reliable comparison between the groups. Despite the limitation of the present study for its retrospective nature, it is an important point that preoperative R.E.N.A.L nephrometry score did not affect the surgeon's technical preference. The main objective with partial nephrectomy is protecting functional kidney parenchyma as much as possible. The procedure is usually performed after temporary occlusion of the renal artery. Because of the significant association between prolonged renal ischemia time and postoperative renal damage, it is suggested that renal warm ischemia time should not exceed twenty minutes (13). Simmons et al. (14) have evaluated the parenchymal atrophy grade by measuring parenchymal thickness before and after the operation and concluded that parenchymal atrophy was more prominent in patients in whom renal warm ischemia time exceeded 40 minutes in partial nephrectomy. Nohara et al. (15) have compared selective and global clamping in partial nephrectomy and reported that there was no significant difference in preoperative and postoperative creatinine levels between the selective clamping group and the global clamping group, whereas the mean creatinine level increased to $1.05 \mathrm{mg} / \mathrm{dl}$ postoperatively from the preoperative $0.9 \mathrm{mg} / \mathrm{dl}$ in the global clamping group. Borofsky et al. (16) demonstrated a $14.9 \mathrm{ml} /$ min decrease in GFR postoperatively compared to preoperative GFR in patients in whom the operation was performed with global ischemia, where as the difference was just $1.8 \mathrm{ml} / \mathrm{min}$ in the regional ischemia group. Harke et al. (17) have also reported a higher decrease in GFR for the total clamping technique when compared to selective clamping technique. There was not any significant difference in our study in terms of preoperative and postoperative eGFR values between the on-clamp and off-clamp techniques at a median follow-up of 27 and 33 months. Another limitation of our study is the small sample size which requires the validation of these findings with further larger patient cohorts. However, considerably longer follow-up time with regard to previous studies is favorable. Considering the transfusion requirements, previous studies did not report any significant difference between selective and global clamping techniques (18). In our study, transfusion requirement was higher in the off-clamp group compared to that in the on-clamp group, however, it did not reach a statistical significance probably due to the low number of patients in both groups. Negative surgical margin status is an important oncological outcome parameter related to tumor size, location and surgical experience. Similarity of the R.E.N.A.L nephrometry scores and maximum tumor diameter between the groups ensured the true comparison of both techniques and, as a result, no significant difference was observed between the groups in surgical margin status.

\section{Conclusion}

In conclusion, both off-clamp and on-clamp techniques are feasible and safe if surgical rules are strictly complied according to the experience of the center and the surgeon. Prospective controlled studies with large patient cohorts are needed for validation of these findings.

\section{Ethics}

Ethics Committee Approval: Ethics committee approval was not obtained because this was a retrospective study, Informed consent: Written informed consent was not obtained from patients because this was a retrospective study.

Peer-review: Internal peer-reviewed.

\section{Authorship Contributions}

Surgical and Medical Practices: Ömer Demir, Güven Aslan, Adil Esen, Concept: Kaan Çömez, Serdar Çelik, Ozan Bozkurt, Design: Kaan Çömez, Serdar Çelik, Ozan Bozkurt, Data Collection or Processing: Kaan Çömez, Serdar Çelik, Analysis or Interpretation: Serdar Çelik, Ozan Bozkurt, Literature Search: Kaan Çömez, Ozan Bozkurt, Writing: Kaan Çömez, Ozan Bozkurt.

Conflict of Interest: No conflict of interest was declared by the authors.

Financial Disclosure: The authors declared that this study has received no financial support.

\section{References}

1. Ljungberg $B$, Bensalah $K_{1}$ Canfield $S$, Dabestani $S$, Hofmann $F$, Hora $M$, Kuczyk MA, Lam T, Marconi L, Merseburger AS, Mulders P, Powles T, Staehler M, Volpe A, Bex. EAU guidelines on renal cell carcinoma: 2014 update. Eur Urol 2015;67:913-924.

2. Thompson $\mathrm{RH}$, Lane BR, Lohse $\mathrm{CM}$, Leibovich BC, Fergany A, Frank I, Gill IS, Blute ML, Campbell SC. Every minute counts when the renal hilum is clamped during partial nephrectomy. Eur Urol 2010;58:340-345.

3. San Francisco IF, Sweeney MC, Wagner AA. Robot- assisted partial nephrectomy: early unclamping technique. J Endourol 2011;25:305-308.

4. Viprakasit DP, Altamar HO, Miller NL, Herrell SD. Selective renal parenchymal clamping in robotic partial nephrectomy: initial experience. Urology 2010;76:750-753.

5. Kowalczyk KJ, Alemozaffar M, Hevelone ND, Ulmer WD, Plaster BA, Lipsitz SR, Yu HY, Hu JC. Partial clamping of the renal artery during robot-assisted laparoscopic partial nephrectomy: technique and Initial outcomes. J Endourol 2012;26:469-473.

6. Gill IS, Eisenberg MS, Aron M, Berger A, Ukimura O, Patil MB, Campese V, Thangathurai $D$, Desai MM. "Zero ischemia" partial nephrectomy: novel laparoscopic and robotic technique. Eur Urol 2011;59:128-134.

7. $\mathrm{Ng} \mathrm{CK}$, Gill IS, Patil MB, Hung AJ, Berger AK, de Castro Abreu AL, Nakamoto M, Eisenberg MS, Ukimura O, Thangathurai D, Aron M, Desai MM. Anatomic renal artery branch microdissection to facilitate zeroischemia partial nephrectomy. Eur Urol 2012;61:67-74.

8. Kutikov A, Uzzo RG. The R.E.N.A.L. nephrometry score: a comprehensive standardized system for quantitating renal tumor size, location and depth. J Urol 2009;182:844-853.

9. Czerny HE. Cited by Herczle: Ueber Nierenextirpation. Beitr Z Klin Chir 1890;6:484-486 
10. Herr HW. Partial nephrectomy for unilateral renal carcinoma and a normal contraleral kidney. J Urol 1999;161:33-34.

11. Fergany $A F$, Hafez KS, Novick AC. Long-term results of nephron sparing surgery for localized renal cell carcinoma: 10 year followup. J Urol 2000;163:442-445.

12. Rosevear HM, Gellhaus PT, Lightfoot AJ, Kresowik TP, Joudi FN, Tracy CR. Utility of the RENAL nephrometry scoring system in the real world: predicting surgeon operative preference and complication risk. BJU Int 2012;109:700-705.

13. Derweesh $I H$, Novick AC. Mechanisms of renal ischaemic injurj and their clinical impact. BJU Int 2005;95:948-950.

14. Simmons MN, Lieser GC, Fergany AF, Kaouk J, Campbell SC. Association between warm ischemia time and renal parenchymal atrophy after partial nephrectomy. J Urol 2013;189:1638-1642.
15. Nohara T, Fujita $H$, Yamamoto $K$, Kitagawa $Y$, Gabata T, Namiki M. Modified anatrophic partial nephrectomy with selective renal segmental artery clamping to preserve renal function: a preliminary report. Int J Urol 2008;15:961-966.

16. Borofsky MS, Gill IS, Hemal AK, Marien TP, Jayaratna I, Krane LS, Stifelman MD. Near- infrared fluorescence imaging to facilitate super-selective arterial clamping during zero- ischaemia robotic partial nephrectomy. BJU Int 2013;111:604-610.

17. Harke $N$, Schoen $G$, Schiefelbein $F$, Heinrich E. Selective clamping under the usage of near-infrared fluorescence imaging with indocya- nine green in robot-assisted partial nephrectomy: a single-surgeon matchedpair study. World J Urol 2014;32:1259-1265.

18. Wang Y, Qu H, Zhang L, Chen S, Xu B, Lu K, Liu C, Tao T, Yang Y, Chen M. Safety and postoperative outcomes of regional versus global ischemia for partial nephrectomy: a systematic review and meta-analysis. Urol Int 2015;94:428-435. 